\title{
Household Food Security and Nutritional Status of Rural Elderly
}

\author{
M A Alam ${ }^{1}$, M A Rahman ${ }^{2}$, M S Flora ${ }^{3}$, M R Karim ${ }^{4}$, M P I Sharif ${ }^{5}$, A Ahmad ${ }^{6}$
}

\begin{abstract}
Household food security is an emerging public health issue and the rural elderly people are one of the most vulnerable groups for the household food security. This cross-sectional study was conducted in Barobaria union of Gofargaon upazila of Mymensingh district to assess the nutritional status of rural elderly ( $\geq 60$ years) in relation to the household food security. A total of 118 purposively selected elderly were interviewed and measured for height and weight following a standard protocol. The mean (SD) age of the respondents was 68.6 (7.3) years and gender participation was equally represented. Majority (68.6\%) of the respondents was illiterate and 92\% were Muslims. Mean family size and monthly family income was estimated to be 5.5 and Taka 6106, respectively and 70\% of the rural elderly were found to be dependent on their family members as they were not involved in income generation and most of the respondents

\section{Introduction}

Food insecurity, under nutrition and poor health status are the most common features of elderly people in rural Bangladesh. Very little is known about the nutritional An older person is defined by the United Nations as someone over 60 years of age. Oldest- old refers to people who are over 80 years of age. There is a steady increase in the proportion of the population aged 60 and above. The majority of older people live in rural areas where services, healthcare provision and access to clean water are more precarious. Older people in Bangladesh experience poverty, have low food security and require targeted assistance. ${ }^{1}$ Due to socio-economical condition the rural elderly people are more victim of socio-economical injustice and the malnutrition is more seen in rural than urban area. Over half of the rural elderly people are at the risk of malnutrition was found in a recent study in Bangladesh. ${ }^{2}$ Availability of food, stability of food supplies and access are therefore three essential determinants of food security. A household can be said to be food secure only if it is secure in terms of both the acquirement and the utilization of food. ${ }^{3,4,5}$ About 20 per cent of rural households live in extreme poverty. Chronically poor people suffer persistent food insecurity, own no cultivable land or assets, are often illiterate and may also suffer serious illnesses or disabilities. Another 29 per cent of the rural population is considered moderately poor. They may own a small plot of land and some livestock, but while they gener

\footnotetext{
1. Dr. Md. Ashraful Alam, Medical officer, NIPSOM.

2. Prof. Dr. Md. Anisur Rahman, WHO Fellow, Professor \& Head Department of Epidemiology, NIPSOM.

3. Dr. Meerjady Sabrina Flora, Associate professor, Department of Epidemiology, NIPSOM.

4. Dr. Md. Rizwanul Karim, Medical officer, NIPSOM.

5. Dr. Md. Parvez Iqbal Sharif, CEO, Diabetic Speciality Centre, Anderkillah, Chittagong.

6. Dr. Ashrafi Ahmad, DPM,Hospital branch BBS.

Corresponding Author
}

Dr. Md. Ashraful Alam, Medical officer, NIPSOM, ashraful.jebu@gmail.com were the members of joint family. Only about $29 \%$ of the total elderly were at the highest quarter of food security. Illiteracy, members of single family and larger family were found to be significantly associated with lower level of household food security $(p<0.05)$. Although age, sex, personal income and occupational category had no significant association, the total family income was significantly associated with household food security. Among the respondents $56 \%$ were underweight including $13 \%$ with severe chronic energy deficiency. Only 5.9\% were overweight. Illiterates were three times more likely to be underweight than literates (OR 2.95 with 95\% CI 1.32, 6.59). Smoking, lower family income, poor housing, single family, irregularity in treatment were significantly associated with underweight. A significant difference was found between mean body mass index of different household food security level $(F=3.22, p<$ 0.05 ). There was gradual increase of mean body mass index with the improved status of food security level. Policy makers, therefore, need to consider programs that empower people to solve the problem of food insecurity and to improve the nutritional status of rural elderly people.

ally have enough to eat, their diets lack protein and other nutritional elements. ${ }^{1,6}$ A recent study conducted in Dhaka found $40 \%$ of their elderly respondents within the optimal range of Body Mass Index (BMI, 18.5-24.9 Kg/m2). Over half $(54 \%)$ of the elderly women were malnourished. Among the elderly ( $\geq 60$ years), males and females from a higher socioeconomic status (SES) had significantly higher BMI ( $p<0.001, p=0.001$, respectively) than their less well-off SES counterparts. ${ }^{7,8}$ This study might help to find out the factors behind poor nutritional status of rural elderly and finally it would help to control the nutritional problem by taking appropriate measures.

\section{Materials and Methods}

This cross sectional study was conducted between January and June 2010 in rural area of Gofargaon upazila of Mymensingh district. The data were collected by face to face interview of 118 elderly. United Nations definitions of elderly ( $\geq 60$ years) including oldest- old ( $\geq 80$ years) were used. In this study nine itemed scale was used which was previously used to measure the household food security level in rural Bangladesh by Shaha KK et al. ${ }^{9,10}$ Food security state was assessed on the basis of nine itemed scale using quartile for14 discrete questions comprising a total score of 59. Bathroom scale up to the $0.5 \mathrm{~kg}$ calibration and a wood stand fixed with measuring tape (stadiometer) were used to measure weight and height, respectively. Weight was measured with minimum clothing and without shoes following standard protocol. Data processing and analyses were done using SPSS (Statistical Package for Social Sciences) version 11.5. Ethical permission was obtained from the Ethical Committee of NIPSOM. 


\section{Results}

Male female participation was almost equal. Majority of the respondents (58\%) were younger old (60-69 years), illiterate $(68 \%)$, belonged to joint family (70\%) and lived in tin-shed houses (46\%). Socio-demographic status of the study samples were detailed in another paper. ${ }^{11}$

Although $56 \%$ of respondents were able to work but only $27 \%$ of them contributed in family income. About $67 \%$ of elderly were given priority in decision making of their households.

Only about $18 \%$ of the households had no history of purchasing rice in last 30 days and $39 \%$ had to buy rice 1-3 times in a month and rest of them had to buy rice 1 to 5 times in a week. About $73 \%$ of the households had to buy kachabazar 1 to 5 times in a week and $23.7 \%$ had to buy 1 to 3 times

Table 1. Socio demographic status with household food security

\begin{tabular}{|c|c|c|c|c|c|c|}
\hline & & Food security & y category & & & \\
\hline Characteristics & $\begin{array}{l}\text { Lowest } \\
\text { quarter of } \\
\text { food } \\
\text { security } \\
n(\%)\end{array}$ & $\begin{array}{l}2^{\text {nd }} \text { quarter } \\
\text { of food } \\
\text { security } \\
n(\%)\end{array}$ & $\begin{array}{l}3^{\text {rd }} \\
\text { quarter of } \\
\text { food } \\
\text { security } \\
n(\%)\end{array}$ & $\begin{array}{l}\text { Highest } \\
\text { quarter of } \\
\text { food } \\
\text { security } \\
n(\%)\end{array}$ & $x^{2}$ & $\mathrm{P}$ \\
\hline Educational statu & & & & & & \\
\hline $\begin{array}{l}\text { Illiterate } \\
\text { Literate }\end{array}$ & $\begin{array}{r}23(28.4) \\
2(5.4)\end{array}$ & $\begin{array}{l}23(28.4) \\
10(27.0)\end{array}$ & $\begin{array}{l}16(19.7) \\
10(27.0)\end{array}$ & $\begin{array}{l}19(23.5) \\
15(40.5)\end{array}$ & 9.535 & 0.023 \\
\hline Family type & & & & & & \\
\hline $\begin{array}{l}\text { Single family } \\
\text { Joint family }\end{array}$ & $\begin{array}{r}17(48.5) \\
8(9.6)\end{array}$ & $\begin{array}{l}14(40.0) \\
19(22.9)\end{array}$ & $\begin{array}{r}3(8.6) \\
23(27.7)\end{array}$ & $\begin{array}{r}1(2.9) \\
33(39.8)\end{array}$ & 35.92 & 0.000 \\
\hline $\begin{array}{l}\text { Occupational stat } \\
\text { Earner }\end{array}$ & $\begin{array}{l}\text { US } \\
\qquad 14(35.9)\end{array}$ & $10(25.6)$ & $9(23.1)$ & $6(15.4)$ & & \\
\hline Retired & $4(13.8)$ & $6(20.7)$ & $6(20.7)$ & $13(44.8)$ & 12.316 & 0.055 \\
\hline $\begin{array}{l}\text { Housewife } \\
\text { Family size }\end{array}$ & $7(14.0)$ & $17(34.0)$ & $11(20.0)$ & $15(30.0)$ & & \\
\hline $\begin{array}{l}\leq 5 \\
>5\end{array}$ & $\begin{array}{r}20(33.3) \\
5(8.6)\end{array}$ & $\begin{array}{l}20(33.3) \\
13(22.4)\end{array}$ & $\begin{array}{l}10(16.7) \\
16(27.6)\end{array}$ & $\begin{array}{l}10(16.7) \\
24(41.4)\end{array}$ & 17.605 & 0.001 \\
\hline
\end{tabular}

in a month and only $3.4 \%$ had not to buy kachabazar. Over half of them $(55.1 \%)$ experienced cooking 1 to 2 times per day but $78.8 \%$ had history of taking complete meals 3 to 4 times a day. Majority of households expended money $(62.7 \%)$ only for food. Among the households more than $25 \%$ gave history of taking help in cooking and $28 \%$ of them had history of taking loan for food security and $6.8 \%$ of the households had to take loan always. Minimum score of household food security was 19 and maximum was 50 and the mean (SD) score was $39.3( \pm 7.8)$. Among the respondents over $21 \%$ were at the lowest quarter of food security, $28 \%$ were at the second quarter, $22 \%$ of the respondents were at third quarter and the rest of them $(28.8 \%)$ were at the fourth quarter with highest food security. Education and size of the family were found to be significantly associated with household food security $(p<0.05)$ whereas the occupation of the elderly showed no significant association with the household food security $(\mathrm{p}=0.055)$ (Table.1) Illiterate were almost 9 times more likely to be lowest level of food security than literate $[\mathrm{OR}=9.08 ; 95 \% \mathrm{CI}(1.84-44.77)$. Family type was revealed as determinant of the household food security for the rural elderly $(\mathrm{p}<0.001)$. Members of single family were almost 70 times more likely to be in the group of lowest level of food security than the members of joint family [OR $=70.13$; 95\% CI (8.09-607.84). Although personal income

Table 2. Significant changes in characteristics of different household food security

\begin{tabular}{|lrr|}
\hline Characteristics & F & P \\
Purchase of rice & 56.90 & 0.00 \\
Purchase of kachabazar & 3.85 & 0.01 \\
No of cooking & 34.72 & 0.00 \\
Frequency of complete meal & 22.72 & 0.00 \\
Frequency of incomplete meal & 64.06 & 0.00 \\
Frequency of taking fish & 50.92 & 0.00 \\
Frequency of taking salt and & 50.02 & 0.00 \\
chili & & \\
Frequency of taking snacks & 25.08 & 0.00 \\
Frequency of festival food & 51.41 & 0.00 \\
Tendency to borrow loan & 11.06 & 0.00 \\
Ability to expend & 51.58 & 0.00 \\
\hline
\end{tabular}

Table .3 Household food security and nutritional status

\begin{tabular}{|c|c|c|c|c|c|}
\hline \multirow{2}{*}{$\begin{array}{c}\text { Food security } \\
\text { level }\end{array}$} & \multicolumn{5}{|c|}{$\operatorname{BMI}\left(\mathrm{kg} / \mathrm{m}^{2}\right)$} \\
\hline & No. & Mean & SD & $\begin{array}{c}\text { Test } \\
\text { statistics }\end{array}$ & $P$ \\
\hline $\begin{array}{l}\text { Lowest quarter } \\
\text { of food security }\end{array}$ & 25 & 17.93 & 2.53 & & \\
\hline $\begin{array}{l}2^{\text {nd }} \text { quarter of } \\
\text { food security }\end{array}$ & 33 & 18.29 & 2.86 & $F=3.227$ & \\
\hline $\begin{array}{l}3^{\text {rd }} \text { quarter of } \\
\text { food security }\end{array}$ & 26 & 19.22 & 3.15 & $d f=3$ & .025 \\
\hline $\begin{array}{l}\text { Highest quarter } \\
\text { of food security }\end{array}$ & 34 & 20.27 & 3.96 & & \\
\hline
\end{tabular}




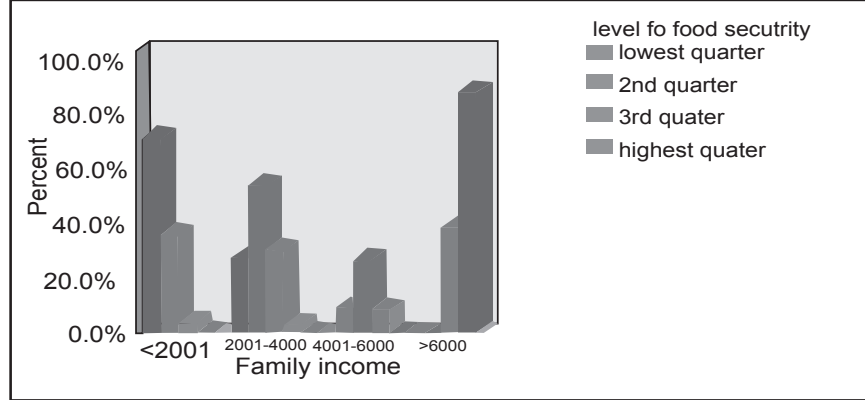

Figure 1. Economic status and household food security

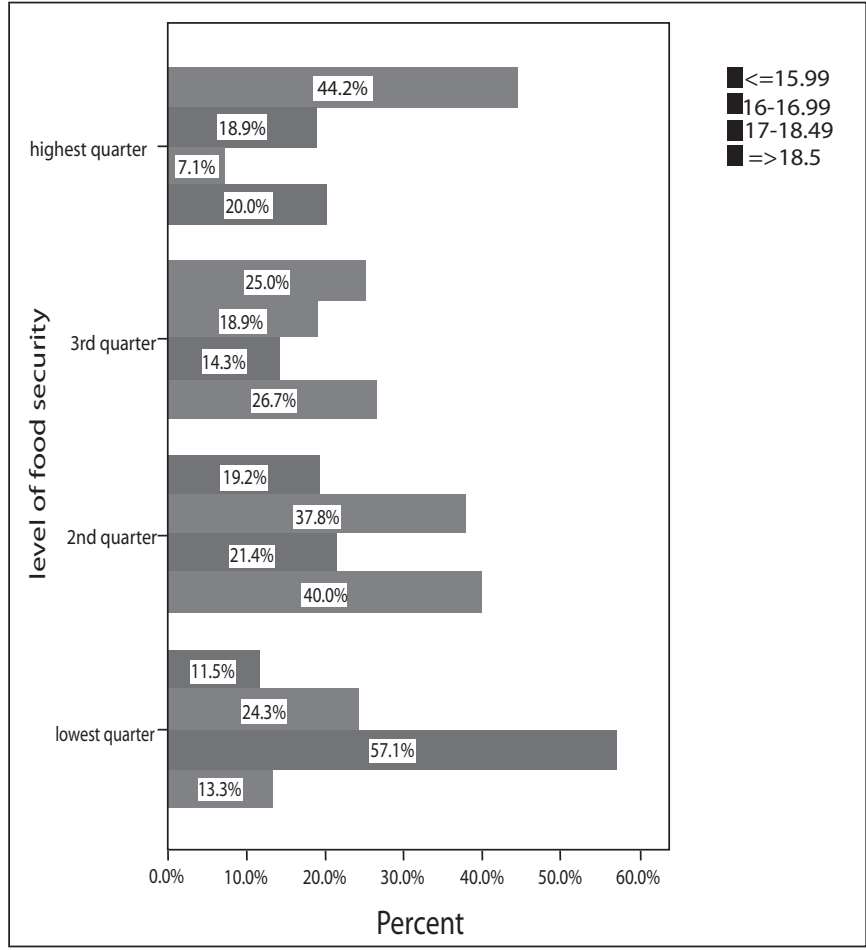

Figure 2. Household food security and nutritional status

of elderly showed no significance but monthly family income showed strong positive correlation with household food security $(r=0.723, p<0.001)$. Among the respondents $55.9 \%$ were underweight group and around 13\% were in severe chronic energy deficiency (CED) and only 5.9\% were in overweight. No particular age group, sex and religion, personal income and occupation were found to be significant with the nutritional status of rural elderly but lower family income, poor educational status, single family, poor housing, and smoker were found to be significant which was shown in another paper entitled "Health and Nutritional Status of Rural Elderly". Ability to income and priority in decision making showed no significant relationship with nutritional status of rural elderly. In case of highest level of food security over $44 \%$ were not underweight whereas in case of lowest level of food security only about $11 \%$ were not underweight. The mean BMI of rural elderly was significant with household food security in this study $(F=3.22, p<0.05)$. It was further noticed that the mean BMI of lowest quarter of food security group differed significantly only from highest quarter of food secure group $(\mathrm{p}<0.05)$ although there was gradual increase of mean BMI with the increase status of household food security level.

\section{Discussion}

This study was done to find out the association of household food security with the nutritional status of rural elderly. The mean \pm SD of age of the respondents was calculated as $68.64 \pm 7.34$ years and over $58 \%$ of the elderly were in the 60 to 69 years age group. It was almost equal to the mean age of elderly previously recorded by Moni et al. ${ }^{11}$ Among the total aged respondents male and female were almost equal. As per BBS, 2008 majority (88\%) of the people of Bangladesh are Muslims. ${ }^{12}$ Current study also found almost the same picture $(91.5 \%$ of the respondents were Muslims).

Regarding educational status, over $68 \%$ of the respondents were illiterate and the rest of them had experience of formal or nonformal education. More than $42 \%$ of the respondents were housewives and retired persons constituted $25 \%$. Almost half of the respondents were female and majority of them were housewives. The average number of family members was $5.53 \pm 2.99$ and it was nearly ${ }_{12}$ equal to the current family size of Bangladeshi population. Although in this study, age group and size of the family did not show any significance with BMI of elderly but different studies in home and abroad, revealed significant association between them. The difference with the present study might varied due to the difference in sample size or sampling technique. ${ }^{7,13-15}$ The average monthly family income of the respondents was $6105.93 \pm 5472.00 \mathrm{Tk}$. and more than half of the respondents were illiterate $(68.6 \%)$ and $67 \%$ respondents were dependent on their family which were almost equal to the findings of Shaila et al. in their study at Sripur upazila. ${ }^{16}$ Among the respondents over $70 \%$ were the members of joint family and about $71 \%$ of the total respondents were some extent of food insecure which were nearly equal to the survey report conducted in 1986 by the Bangladesh Association for the Aged and Institute of Geriatric Medicine (BAAIGM) on persons aged 60 years and above indicated an improvement in life expectancy. ${ }^{17}$

Among the respondents over $21 \%$ were at the lowest quarter of food security and about $29 \%$ were at the highest quarter of food security. Although age, sex, personal income and occupational category had no significant association but the total income of the family, literacy of the rural elderly, types of family were significantly associated with the food security of rural elderly. Among the respondents $55.9 \%$ rural elderly were underweight and over half $(57.7 \%)$ of the elderly women were some extent of underweight which was almost equal to the findings of the study of Faruque A et al. ${ }^{7}$ Among the elderly males and females from a higher socioeconomic status had significantly higher BMI than their less well-off socioeconomic status counterparts. There was gradual increase of mean BMI with the increase status of household food security level. It showed similarity with the findings of the study of Faruque A et al. $7,13,14$

\section{Conclusion}

This study addressed the nutritional status of rural elder persons in different household food security level and revealed that food insecurity is an important risk factor associated with poorer nutritional status among rural older persons and there was gradual increase of nutritional status of rural elderly with the improved status of rural elderly. Programs should be taken to increase the food security and to reduce the vulnerability of rural elderly by improving nutritional status. Although this study found a significant association between the food security and the nutritional status of rural aged people, the association doesn't mean any causal inference as the study was a cross sectional in 
design. Therefore a better analytical study might be done by using this study as a baseline data to have a complete conclusion.

\section{References}

1. Kabir ZN, Ferdous T, Cederholm T, Khanam MA, Streatfield K, Wahlin A . Mini Nutritional Assessment of rural elderly people in Bangladesh. Public Health Nutr 2006; 9:968-74.

2. FerdousT, Cederholm T, Razzaque A, WahlinA, Kabir ZN. Nutritional status and self-reported and performance-based evaluation of physical function of elderly persons in rural Bangladesh. Scandinavian Journal of Public Health, 2009; 37: 518-524.

3. Riely F, Mock N, Cogill B, Bailey L and Kenefick E. Food Security Indicators and Framework for Use in the Monitoring and Evaluation of Food Aid Programs. Food and Nutrition Technical Assistance Project; January 1999. 4.http://www.ifad.org/hfs/thematic/rural/rural_2.htm.Ma y 20, 2010.

5. Shariff ZM and Khor GL. Household food security and coping strategies in a poor rural community in Malaysia. Nutrition Research and Practice (2008), 2(1),26-34.

6. http://cc.bingj.com, Rural poverty in Bangladesh,IFAD, may 24, 2010.

7. Faruque ASG, Khan AI, Roy CN, Malek MA, Salam MA and khaled MA. Anthropometric characteristics of elderly people:Observations at a large diarrheal hospital in Dhaka, Bangladesh.Southeast Asian J Trop Med Public Health 2006;37 No.784-91.

8.Availablefrom:http://www.helpage.org/Researchandpol i c y / A g e D e m a n d s A c t i on 2008 / C o un t r y Profiles/Bangladesh, May 18, 2010.
9. Saha KK, Frongilo EA, Alam DS, Arifeen SE, Persson LA, Rasmussen KM. Household food security is associated with growth of infants and young children in rural Bangladesh. Public Health Nutr. 2009 Jun; 12(6):884.

10. Frongillo EA, Chowdhury N, Ekstrom EC and Naved RT. Understanding the experience of household food insecurity in rural Bangladesh leads to a measure different from that used in other countries. J. Nutr.133: 41584162,2003.

11. Moni MA, Rahman MA, Haque MA, Islam MS, Ahmed K. Blood pressure in relation to selected anthro pometricmeasurements in senior citizens. Mymensingh Med J 2010Apr; 19(2): 254-58.

12. Bangladesh Bureau of Statistics. Statistical Pocket Book of Bangladesh 2008. Dhaka: Planning Division, Ministry of Planning, Government of the people's Republic of Bangla desh; January 2009.

13. Frongillo EA, Chowdhury N, Ekstrom EC and Naved RT. Understanding the experience of household food insecurity in rural Bangladesh leads to a measure different from that used in other countries. J. Nutr.133: 4158-4162,2003.

14. Chilima DM, Ismail SJ. Anthropometric characteristics of older people in rural Malawai. Eur J Clin Nutr 1998;52:643-9.

15. Fischer J, Johnson MA. Low body weight and weight loss in the aged. J Am Diet Assoc 1990; 90:1697-706.

16. Ahmed S, Shirin S, Parvin MN, Sultana N, Sayed S et al. Geriatric health problems in a rural community of Bangladesh. Ibrahim Med. Coll. J.2007;1(2):17-20.

17. Rashid KM, Rahman M, Hyder S. Textbook of Community Medicine and Public Health. 4th edition, Bangladesh 2004: 518-521.

Scandinavian Journal of Public Health, 2009; 37: 518-524. 